\title{
BRITISH LEGISLATION \\ AS A SOURCE OF GHANAIAN LAW: FROM COLONIALISM TO TECHNICAL AID
}

\author{
By Gordon WoOdMaN
}

This article will discuss a curious phenomenon of the colonial and post-colonial legal history of Ghana: the application, as part of the law of Ghana, of statutes enacted by the British parliament. The earlier history of the subject has been treated by other writers. Recent developments have not been discussed elsewhere, and raise new issues. The discussion will consist of a chronological account in two stages, giving particular attention to matters which are of significance today, followed by a discussion of the policy issues involved. During the colonial period the territory which is now Ghana was called the Gold Coast, but for convenience it will generally be referred to as Ghana throughout.

\section{From the Establishment of the Colonial Regime, 1874-76, to Independence, 1957}

A series of legislative acts in the years $1874-76$ is a convenient starting-point. Previous experiments in colonial government were repealed, and a new Legislative Council and Supreme Court established. These continued in existence almost unchanged until shortly before independence, and may reasonably be regarded as predecessors in title of the present legislature and judiciary. The Gold Coast Colony was at that time only a fraction of present-day Ghana, and was administered together with Lagos, now part of Nigeria. But for the purpose of exposition of the sources of law, it is convenient to treat subsequent territorial changes as additions to and subtractions from the original colony, the legal system of which has been extended to each added area.

The colonial power established a legislative council in the colony in 1874, its powers, membership and processes being, of course, designed to ensure subordination to the policies of the British government. However, so long as Ghana remained a colony, the British parliament, by British constitutional law, retained legislative powers over it. The establishment of a local legislature did not affect this, because in constitutional theory the British parliament cannot irrevocably cede its powers, except by a grant of full independence. Thus it was able to continue to legislate for Ghana, and its legislation, where applicable to Ghana, prevailed over that of the legislative council. However, parliament did not wish all its enactments to apply to the colonies. By the Colonial Laws Validity Act, 1865, it had been provided that, whenever a local legislature was established for a territory, Acts of the imperial parliament were thenceforth not to be construed as extending to that territory unless this was indicated by express words or necessary intendment.

Thus British statutes enacted after 1874 did not all automatically apply in Ghana. However, a small but steady stream of statutes was expressly made applicable. These statutes were of two types: constitutional enactments, such as the Foreigre Jurisdiction Acts, 1890-1913, concerning the jurisdiction of British courts outside 
Britain; and enactments designed to produce uniform rules throughout the British empire in particular spheres of law, such as the Colonial Prisoners Removal Act, 1884, authorising the moving of prisoners between different British colonial territories.

The British Crown had under a number of British Acts ${ }^{1}$ power to legislate for the colony by order in council or letter patent. These also overrode ordinances of the legislative council. They were used for the enactment inter alia of the successive colonial constitutions.

The instances so far discussed may be classified as one type of British legislation in force in Ghana: legislation enacted by or under the authority of the British parliament after 1874 , and intended to apply to Ghana.

The legislative council in 1876 established a Supreme Court to hear all the more important cases which arose in the colony. It was necessary to provide for the law to be applied by this court. It was bound by the British legislation already mentioned. It was also to apply ordinances enacted by the legislative council, and subordinate legislation made under such ordinances. These enactments, however, did not amount to a comprehensive body of law. The enactment of comprehensive codes was not in the British tradition, and did not occur apart from the enactment of a Criminal Code in 1892. The Supreme Court Ordinance, 1876 (called in later re-enactments the Courts Ordinance) accordingly provided that two other bodies of law were to be applied by the Supreme Court: "native law and custom", today called customary law; and "English law". The ordinance provided rules for determining which system of law was to apply in each case before the court. Customary law has now grown into an imposing edifice, but it is not of great relevance to the present subject, and need not be analysed. "English law" must be further examined. The general policy was clear; to apply in the colony the law in force in England. Much of this was a large body of case-law, established in the courts of common law and equity over the centuries. It was assumed that this could be applied without difficulty. Accordingly the ordinance included, in the category of "English law", "the common law" and "the doctrines of equity". However, these principles had over the centuries been amended and added to by English statutes. Here the reception of English law raised greater difficulty.

To exclude this English statute-law altogether would clearly have been absurd. This would have been to revive every anomaly, abuse and inadequacy in English law which had ever been removed by statute. It would have required the Supreme Court to apply a totally unsuitable mediaeval law which it could not even have discovered without extensive historical research. At the same time, however, to apply all English statutes without exception would also have been unsatisfactory. Those enacted by the British parliament after the institution of the legislative council did not automatically apply in Ghana, as we have seen. The council could have enacted that they were to apply, but this would have amounted to an abdication of the council's responsibility for directing the legal development of the colony. Even to apply all English statutes enacted before that date would have resulted in the enforcement of many designed for specifically English problems. The Supreme Court Ordinance therefore provided for the application, in cases

1 The most notable was the British Settlements Act, 1843, later re-enacted in the British Settlements Act, 1887. There were also many minor Acts, e. g. the Patents and Designs Act, 1907. 
governed by English law, of "the statutes of general application which were in force in England at the date when the Colony obtained a local legislature, that is to say, on the 24 th day of July, 1874 ".

This was qualified by a further provision that all British statutes applicable in Ghana were to be so only so far as local circumstances permitted, and could be construed with such verbal amendments as might be necessary to render them applicable. 'This opportunity for modification was rarely used.

The phrase "of general application in force in England" was once judicially castigated as "a slovenly expression, made use of by the Legislature of this Colony to save itself the trouble of explicitly declaring what the actual law of the Colony shall be ${ }^{2}$ ". It gave rise to some difficulty in the cases and a large discussion in the texts ${ }^{3}$. The view generally followed seems to have been that the phrase referred to statutes applicable throughout England, to the entire conmunity or the entirety of a substantial class within the community, and (in most cases) applicable by all English courts.

This, then, was a second class of British legislation in force in Ghana during the colonial period. It applied only in those cases governed by "English law", and was subject to the overriding effect of the first class and of local legislation. It was a class which could not increase in size, and tended to diminish. As the legislative council (and later the legislative assembly and the parliament) enacted more legislation, the English statutes were gradually superseded. Thus the Criminal Code of 1892 replaced all English criminal statutes. However, the rate of local legislation was slow, and many English statutes of general application remained in force at independence.

A few areas of law were subject to different terminology. The Supreme Court Ordinance provided that the jurisdiction of the court "in Probate, Divorce and Matrimonial Causes and proceedings may ... be exercised ... in conformity with the law and practice for the time being in force in England". Since divorce is a matrimonial cause, this affected only two areas of law. The meaning of the phrase "for the time being in force" was for many years a matter of doubt, but it was generally assumed, and in the end authoritatively decided that it empowered a court to apply the law which an English court would have applied had it been deciding the same case at the same date. The use of "may" meant that the courts were not compeiled to apply this law, but they invariably did so. Thus English statutes automatically took effect in Ghana as soon as they took effect in England. This occurred not because of the British parliament's power to override Ghanaian law, as in the case of the first class discussed above, but because the local legislature had provided that this was to occur. It is therefore a third, distinct class of British legislation applicable in Ghana. It was not significantly altered by local legislation before 1957.

It is convenient to mention here also the Supreme Court (Civil Procedure) Rules, 1954 (L. N. 140A), made under the Courts Ordinance. Order 74 provided that, where no provision was made in the Rules, "the procedure, practice and forms in

\footnotetext{
2 Des Bordes v. Des Bordes (1884) Sar. F. C. L. 267.

3 See: Redwar, Comments on Some Ordinances of the Gold Coast Colony (1909), pp. 8 et seq; Allot Essays in African Law (1960), pp. 9-10; Bennion, The Constitutional Law of Ghana (1962), pp. 395-398; Daniels, The Conmon Law in West Africa (1964), pp. 319-346. These discuss Ghanaian law specifically. There has been n!uch more literature on similar provisions in the laws of other British colonies.

4 Ashong v. Ashong (1968) C. C. 26; held unaffected by the 1969 Second Republican Constitution, Crabbe v. Crabbe [1971] 2 G. L. R. 164.
} 
force for the time being in the High Court of Justice in England" were to apply in the Supreme Court (later the High Court) as far as this could conveniently be done. This applied the same class of British statutes as for probate and matrimonial causes, but it applied them only to those parts of this area of law where there was no provision in the Ghanaian enactment.

The Supreme Court Ordinance provided that the court was to have "all and singular the powers and authorities of the Lord High Chancellor of England", and mentioned specifically the powers in respect of infants and persons of unsound mind. There is no reason to suppose that this did more than apply "English law", including any relevant statutes of general application in force in England in 1874. This was therefore another instance of the second class.

The admiralty jurisdiction of the court was dealt with differently. After the enactment in Britain of the Colonial Courts of Admiralty Act, 1890, the Supreme Court Ordinance was amended to require the court to exercise its admiralty jurisdiction "by virtue and in pursuance" of the Act. The Act provided that all British enactments affecting the jurisdiction of the English High Court in its admiralty jurisdiction should apply in colonies which had so adopted the Act. This was interpreted to include enactments in force at the date of the passing of the Act ${ }^{5}$. This constitutes a fourth, very small class.

Further classes of British statutes were added to the law of Ghana by other enactments. When the Ghanaian legislature enacted new statutes they were of ten substantially reproductions of British statutes. For example the Moneylenders Ordinance, 1940, reproduced verbatim much of the British Moneylenders Act, 1927. The reasons for this will be discussed below. This was not a case, like those previously noted, of British statutes qualifying to apply in Ghana merely by virtue of their enactment in Britain. In this case the British statute was a historical or literary source rather than a legal source of Ghanaian law ${ }^{6}$. Nevertheless, there was little practical difference between the enactment of a Ghanaian Moneylenders Ordinance reproducing the British Act, and the result which would have ensued if the Ghanaian legislature had enacted a one-section ordinance providing that the British Act should be in force in Ghana.

Special provision was made by a Ghanaian ordinance for a part of the English law of inheritance to apply in Ghana. The Marriage Ordinance, 1884, introduced a form of monogamous marriage, to be contracted according to formalities modelled on those of the English Marriage Acts. It was considered that this form of marriage should entail an English form of inheritance. The ordinance therefore provided that in certain circumstances, where an intestate had been married under the Marriage Ordinance, or was the issue of such a marriage, his estate should be distributed according to English law. However, the English law of intestacy at that time was considered to be archaic and unsuitable for Ghana. It consisted of one set of rules for realty (which was generally, but not entirely coincidental with immovable property), under which the basic principle was male primogeniture; and a different set of rules for personalty, under which the property was shared in fixed proportions among the closest relatives. The latter set, which was mainly statutory, was considered suitable in Ghana for all property. The Marriage Ordinance therefore provided that all property was to pass "in accordance with

5 The Yuri Manu, The Woron [1927] A. C. 906.

6 Salmond on Jurisprudence (10th ed. 1947 ed. Williams), para. 47. 
the provisions of the law of England relating to the distribution of the personal estates of intestates". The English law was to be that in force on the date of commencement of the Marriage Ordinance, 19th November 1884. This law consisted primarily of the Statutes of Distribution, 1670 and 1685, and is known as "the statutes of distribution". By two Marriage Amendment Ordinances, 1909, the operation of this law was reduced to affect only two-thirds of each estate, the remainder passing under the customary law.

To summarise, the following classes of British statutes were part of the law of Ghana during the colonial period:

(1) Legislation enacted by the British parliament, i. e. the king (or queen) in parliament, or by the British Crown, after 1874, and intended to apply to Ghana.

(2) Statutes of general application in force in England in 1874.

(3) Statutes "for the time being in force in England" in the spheres of probate and matrimonial causes, and in procedural matters in the Supreme Court.

(4) Statutes governing the admiralty jurisdiction of the English High Court in force in 1890 .

(5) Statutes the texts of which had been enacted by the Ghanaian legislature.

(6) The statutes of distribution.

\section{Since 1957}

During the colonial period, the existence of British statutes in Ghana could always have been a result of imperial pressure, rather than local choice. While freedom of choice is not necessarily secured by legal sovereignty, it may be expected that the form of Ghanaian law has since 1957 increasingly come to represent Ghanaian choices. It is thus of interest to find much British statute-law still applying in Ghana.

Class (1), the British legislation which overrode all Ghanaian law, was necessarily affected by independence. The 1957 Independence Constitution was itself a British enactment, and initially it imposed some restrictions on the powers of the Ghanaian legislature. The First Republican Constitution, 1960, established indisputably that there was no longer any British legislative power over Ghana. All enactments of the present class which limited Ghana's legislative sovereignty were therefore repealed, either expressly or impliedly. This did not apply to enactments the substance of which was consistent with the new constitution, although these continued only at the will of the Ghanaian legislature. Some were replaced by Ghanaian statutes in the succeeding years. Thus the British Fugitive Offenders Act, 1881, and Extradition Acts, 1906 and 1932, were replaced by the Ghanaian Extradition Act, 1960 (Act 22). A few lingered on, of no importance and never requiring application, until the Courts Act, 1971 (Act 372), in a section to be examined below, swept them away.

Class (2), statutes of general application in force in England in 1874, has not yet completely disappeared. The legislation for the constitutional arrangements of 1960 contemplated its imminent demise. The Courts Act, 1960 (C. A. 9) repealed the Courts Ordinance but provided in s. 154 that this should not affect the continued application of the statutes of general application then in force, nor the existing jurisdiction in respect of infants and persons of unsound mind. The Inter- 
pretation Act, 1960 (C. A. 4), s. 17, defined "the common law, as comprised in the laws of Ghana" as consisting primarily of the rules of common law (in a narrow sense) and the doctrines of equity. The Act then added that "while any of the statutes of general application continue to apply by virtue of the Courts Act, 1960 (C. A. 9), they shall be treated as if they formed part of the common law ..." However, this arrangement continued for 12 years $^{7}$. The only change during this time was a continuation of the process whereby particular English statutes ceased to be in force as Ghanaian legislation was enacted on the same subjects.

An important development towards the elimination of this type of legislation, as well as towards its ascertainment while it remains, was contained in the Courts Act, 1971. This Act repealed the previous Courts enactment, and in s. 111 provided generally that "the statutes of England shall cease to apply in Ghana", subject to certain exceptions. One exception was relevant here. It was still not considered possible to exclude these statutes altogether. The Act therefore retained in force certain specified British statutes which were listed in the First Schedule to the Act. An authoritative list having thus been provided, the meaning of "of general application in force in England" has ceased to have practical implications. The list consisted of 39 English Acts, from most of which only certain sections were to be in force. The Act also enacted rules concerning jurisdiction over infants and persons of unsound mind in ss. 16 and 17, and no British statutes on these matters were listed.

Subsequent enactments have reduced the list to about half its 1971 length. Statutes have been removed either because they seemed to have no significance or because they had been superseded by Ghanaian enactments passed after the Courts Act, $1971^{8}$.

Class (3), statutes "for the time being in force in England", has also been greatly reduced. The 1960 legislation retained it on the same temporary basis as statutes of general application ${ }^{9}$. English probate law was largely replaced by the Administration of Estates Act, 1961 (Act 63), and finally abolished by the Wills Act, 1971 (Act 360), s. 19. The critical development in respect of matrimonial causes occurred when the British parliament radically revised the English law of divorce by the Divorce Reform Act, 1969. It was found that this took automatic effect in Ghana on its date of commencement in England, 1st January 1971. The Ghanaian legislature then passed the Matrimonial Causes Act, 1971 (Act 367), which replaced the English law. The text of the Ghanaian Act is based on the English Act of 1969, with changes in important details. The Courts Act, 1971, contains no provisions corresponding to those which brought British statutes into force for these areas of law. However, British statutes of this class regulating aspects of procedure in the High Court not covered by the Ghanaian rules, have remained. The Courts Act, 1971 , s. 111, in discontinuing British statutes made an exception "in so far as they may be applied by any enactment for the time being in force", and retained in force the Supreme [now High] Court (Civil Procedure) Rules, 1954. British statutes are occasionally applied on this ground ${ }^{10}$.

\footnotetext{
7 The Courts Act, 1960, was repealed by the Courts Decree, 1966 (N. L. C. D. 84), which by para. 93 retained the statutes of general application then in force.

8 See e. g. the Courts (Amendment) (No. 2) Decree, 1972 (N. R. C. D. 137), s. 2. Among the Acts discontinued by this decree the Distress for Rent Act, 1689, is an example of Acts considered insignificant. while the Mortgage Act, 1733, had been superseded by the Mortgages Decree, 1972 (N. R. C. D. 96).

9 Courts Act, 1960, s. 154, the effect of which in this respect was continued by the Courts Decree, 1966,

10 See e. g. Republic v. Boateng ex parte Adu-Gyamfi II [1972] 1 G. L. R. 317.
} 
Class (4), concerning admiralty jurisdiction, was also retained in $1960^{11}$, but not by the Courts Act, 1971, which in s. 18 made express provision for jurisdiction in maritime matters.

Class (5), British statutory texts enacted by the Ghanaian legislature, has increased in bulk and importance. It has just been seen that this process has accompanied the reduction or elimination of classes (1), (2), (3) and (4), in that Ghanaian statutes have often enacted the texts of British statutes while providing that the British statutes as such should cease to apply. In addition, in some cases the texts of modern British statutes, which had not been in force in Ghana, have been adopted. For example, the Ghana Limitation Decree, 1972 (N. R. C. D. 54) is closely based on the British Limitation Act, 1939. In such cases the British statutes which cease to apply, if any, are those which had governed the subject in England before 1874. In effect the Ghanaian legislature has incorporated into Ghanaian law the British modernisation.

Class (6), the statutes of distribution imported by the Marriage Ordinance, remains in force. We have seen that the Courts Act, 1971, s. 111, providing that British statutes should cease to apply in Ghana, makes an exception for those applied by any enactment for the time being in force. The Marriage Ordinance remains in force.

During this period a class (7) has been created, probably temporarily. The Courts Act, 1971, s. 111, in addition to the provisions already discussed, enacted that "until provision is otherwise made by law" 55 specified sections of the British Law of Property Act, 1925, were to be in force in Ghana as part of the "common law" of Ghana, with verbal amendments where necessary. (In some instances, only certain subsections of these sections were included.) Most of these provisions had not previously been in force in Ghana, although a few were re-enactments of earlier British statutes which had been in force as statutes of general application ${ }^{12}$. It is probable that this development will not remain effective for long. By the Conveyancing Decree, 1973 (N. R. C. D. 175) Ghana has enacted the text of almost all the sections of the Law of Property Act, 1925, received in 1971, with some modifications. The Conveyancing Decree does not provide that these sections shall cease to be in force, but since it replaces them it may be expected that a subsequent statute will formally remove them from the statute-book. Thereafter the only trace of this departure for practitioners will be the inconvenient fact that for two years conveyances were governed by the British Act. Otherwise this area will be affected only by the decree, which falls into class (5), British statutory texts enacted in Ghana.

A long-standing problem in the application of British statutes has been that they are not readily available in Ghana. While Ghanaian enactments are printed in Ghana and widely distributed in the country, British statutes such as the Law of Property Act, 1925, are almost inaccessible even to practitioners. The Courts Act, 1971 , sought to meet this problem in s. 111. It empowered the Minister responsible for Justice to prepare a volume containing all the provisions of British statutes in force in Ghana by virtue of that section, with minor amendments and rearrangement where suitable. When this volume had been approved by the National

11 Note 9 above.

12 Thus the Law of Property Act, 1925, ss. 40, 52-55, substantially re-enacted the Statute of Frauds, 1677, ss. $1-4$. 
Assembly it was to become the authoritative text of the statutes. It seems likely that this will not need to be implemented. As we have seen, the list of statutes of general application has been reduced, and the adopted provisions of the Law of Property Act, 1925, have almost all been incorporated in the Conveyancing Decree, 1973. Moreover, as a result of the military coup of January, 1972, the legislative process has become much simpler. The simplest solution to the problem today would be the enactment of a few decrees incorporating the text of the remaining British statutes which have not been enacted in Ghana. The Law Reform Commission has recently been considering draft decrees for this purpose.

The present trend is towards the elimination of all British statutes applicable per se in Ghana, but towards an increase in the number of Ghanaian statutes with texts derived from the British statute-book.

\section{Policy Considerations}

What are the arguments for and against the application of British statute-law in Ghana? It seems reasonable to place the onus of proof on those who advocate the adoption of British statute-law. If Ghana were to repeal and forget all existing law, and start afresh designing a legal system for her society (to pose an impossible hypothesis) the mind of a neutral legislator would hardly leap to the idea that Ghanaian law should include a large measure of British statutes. Thus we may approach the question by asking what justification there can be for this.

The original decision-making was British. There was one overwhelming reason why, in the eyes of the imperial power, elements of its legislation should apply in Ghana: the maintenance of its legal authority required that it should be able to legislate for Ghana, and that the local government should derive its powers from British legislation. Had the Ghanaian legislature been unlimited, Ghana would have ceased to be a colony. This argument went to justify some enactments of class (1), legislation enacted in Britain with the intention that it apply to Ghana. It did not necessarily follow that this power should be used in all the cases where it was used, nor that any other types should apply in Ghana. The argument derives any validity it may have from the arguments in favour of colonialism, and the arguments against it are those against colonialism. It is not intended to explore those very wide issues here.

There were other arguments which were influential in decisions to make British statutes parts of Ghanaian law. One was simply that English law was the most desirable system of law for Ghana. Therefore it ought to be applied, including the statutes which were part of it. The choices before the government in framing a legal system for Ghana were few. It was not prepared to invest in the expertise necessary to design a unique Ghanaian law. The one limited exception to this was the drafting of the Criminal Code. However, this was not entirely unique to Ghana. It was essentially a codification with amendments of the English criminal law, based on codes designed for other colonies, and part of a general colonial policy of establishing codes of criminal law. There was no such policy for other areas of law. It would not have been practicable to apply the law of another state, such as France, in Ghana, even had the British wished to do so, again because of lack of expertise. Scots law was not seriously considered: presumably the predominantly English decisionmakers thought it inferior. The effective choices were there- 
fore between the indigenous customary law and English law. As between these, there was little doubt in the British government's mind that English law should at least be introduced to co-exist with customary law, and that it had a more hopeful future in the evolutionary struggle for survival. This could be illustrated from many examples, but one may suffice. In 1911 the courts were faced with a dispute concerning the proper interpretation of the Land Registry Ordinance. One of the views proposed was that a registered grant of land should invariably prevail over a conflicting unregistered grant of the same land. Customary law grants were of their nature unregistrable. This interpretation would therefore have eliminated the customary law of conveyancing as a reliable procedure. Nevetheless it was accepted by the Full Court of the Supreme Court, which said that sales of land under customary law were infrequent and becoming rarer "except in the bush" (which apparently meant everywhere outside the larger coastal towns); probably, therefore, the legislature had deemed it wiser to pay no heed to them ${ }^{13}$.

In so far as this argument asserts that English law is inherently superior to any other system, the main objection is to its basic assumption that systems of law can be judged against an absolute standard. Most thinkers today would doubt whether the value of a legal system can be judged without reference to the particular social circumstances in which it is applied ${ }^{14}$. The argument that English law is the best system for Ghana might, however, be put in a more moderate form. It might be accepted that law should be framed to effectuate a society's own values ${ }^{15}$. It might then be argued that, taking account of Ghanaian circumstances, English law happens to be the most suitable system for Ghanaian society. This argument may be advocated in respect of some areas of law only. It appears that this qualified view was also influential with the early legislators. Thus they allowed customary law to continue in force, particularly for the determination of disputes between "natives" (in the terminology of the Supreme Court Ordinance). Moreover, as we have seen, where English law was to be applied, it was not normally to include British statutes enacted after the institution of the legislative council in 1874. From that date it was left to the local legislators to decide whether to adopt British statutes singly by enacting them, and whether in adopting them to make amendments for local conditions.

The principles originally adopted can hardly be regarded as having identified precisely that type of English law which would be suitable for Ghana. For example, the general exclusion of post 1874 British statutes meant that defects in the earlier law, which were removed in England after 1874, continued to exist in Ghana. Thus there was a rigid rule of English conveyancing that to convey a fee simple estate inter vivos to $\mathrm{X}$ it was essential to use the words "to $\mathrm{X}$ and his heirs" in the deed of conveyance. No other words were sufficient, however clear it might be that the grantor in fact intended to convey a fee simple. In England the rule was modified in 1882 to allow the use of the words "in fee simple", and finally abolished by the Law of Property Act, 1925, on the ground that in practice an intention to pass a fee simple was usual, and therefore could be presumed unless a contrary intention was expressed. These statutory amendments did not take effect

13 Concession Enquiries 1016 and 1035 (Sekondi) (1911) Ren. 592. This interpretation was later rejected.

14 See e. g. Pound, Introduction to the Philosophy of Law (Rev. ed. 1954), Chap. 2.

15 Ibid. 
in Ghana, where the archaic rule remained until the Courts Act, 1971, adopted this provision of the Law of Property Act. Thus, unless Ghanaian conditions are more like those of mid-nineteenth century England than of modern England, the argument of suitability would have been stronger in respect of the law "for the time being in force" then in respect of statutes of general application. The error here was the failure to foresee that, in some areas at least, the Ghanaian legislature would be even more dilatory than the British in reforming the common law. However, the example merely shows that the type of English law chosen was not as suitable for same aspects of Ghanaian law as a different type of English law might have been.

The counter-argument to the view that English law is suitable for Ghana is that English law is most unlikely to be suitable for application in a society considerably different from that in which it developed. Moreover, it cannot be assumed a priori that economic development will tend to make Ghanaian society resemble English society more closely. Further, taking statute-law in particular, none of the British statutes which were applied in Ghana, except those of class (1), were designed with Ghanaian circumstances in mind.

The official policy has never been a total acceptance or a total rejection of British statute-law. The development has been towards a continued, and perhaps increased acceptance of British statutes, but with increasingly careful adaptation of their details to Ghanaian circumstances. We have seen that the number of British statutes directly applicable in Ghana has been greatly reduced, but that an increasing number of Ghanaian statutes has incorporated the texts of British statutes. The British statutes considered suitable for Ghanaian conditions today generally fall into two classes. Firstly, there are some areas of activity for which customary law has developed no provisions. Statutes have enacted British law for such purposes, as for example in the Companies Code, 1963 (Act 179). This Act, like many others, follows British law substantially in outline, although containing important and interesting variations for Ghanaian circumstances. Secondly, English law has remained a component of Ghanaian law, under the name "common law", and here British amending statutes are often considered suitable, as is shown by the Limitation Decree mentioned above. However, there has recently been a third sphere for which British statutory texts have appeared suitable. While customary law has flourished in some areas, it has also been found in need of reform. There has been a tendency to reform it with British legislative texts. For example, the Limitation Decree and the Conveyancing Decree not only amend common law by the use of English texts, but also generally apply these texts to customary law.

These developments indicate some current opinions. It is possible, although not proven, that elements of the Ghana legal profession still consider English law to be inherently superior to other types of law. While today the profession is composed almost entirely of Ghanaians, most practitioners have received their professional education in England, English legal customs (such as court dress) are followed, and English decisions carry considerable weight in the Ghanaian courts. However, there is probably also (or rather) a reasoned view that British statutes are, for some purposes, and with some adjustments, suitable for Ghanaian circumstances. The process of developing a unique, Ghanaian law is progressing, but during this process it has been found useful to incorporate some English legislation. The modern method of enacting British texts in Ghanaian statutes is less open to the 
objection of unsuitability. Whenever a Ghanaian statute is drafted, a number of people necessarily consider the applicability of each detail of each section to Ghanaian circumstances, and there is a possibility of making detailed alterations. This was not the case with the "blanket" adoptions of types (2), (3), (4) and (6). Such adaptations have perhaps not been done as fully as might have been desirable. For example, although the Limitation and the Conveyancing Decrees expressly apply to customary law, they do not answer some of the major questions which will arise from this. Thus each makes special provisions for "leases", but neither indicates which customary-law transactions should be regarded as leases. Nevertheless, it is in general less probable today that British legislative texts will take effect in Ghana when they are totally unsuitable. The present official view seems to be that British statutes are, in certain areas and with some adaptation, suitable for application in Ghana.

Another argument for the application of English law which probably weighed with the colonial regime was the importance accorded to the interests of Europeans in Ghana. The body of white settlers was never large, but was undoubtedly influential. There was also a body of expatriate civil servants throughout and for a period after the colonial period. All of these were likely to be opposed to personal subjection to customary law. Therefore the colonial regime wished English law, including statutes, to apply to the affairs of Europeans. It is possible that such a policy is still influential, although the question has not been fully investigated. Foreign businesses are important, and no doubt influence legislation. However, their objectives, if rationally based, would seem to be certain general objectives such as certainty in the legal effects of transactions, and low taxation for themselves, regardless of how the legislative draftsman achieves them, rather than towards law of a specifically English character.

A minor argument for the application of British statutes is that it produces uniformity of laws. In certain matters, such as extradition, it is convenient if as large a number of states as possible have identical laws. This can be achieved if laws framed in one state are made parts of the laws of others. The validity of this argument, taken in isolation, can probably not be challenged. It is, however, subject to the counter-argument that the process requires the receiving state to abdicate its power of choice. This argument concerning national sovereignty will be developed further below. Because of it the preferred method of achieving uniformity today is for states to enact their own laws, but to endeavour to bring them as close to international practice as is consistent with national policy. Thus, as has been mentioned, Ghana has enacted her own Extradition Act.

An argument which may have carried weight in colonial times, and seems to be the strongest argument of all today, is concerned with the high technical skill which is required for legislative drafting. Development, one of the main objectives of Ghana today, requires considerable legislative activity, but Ghana is short of this skill. British statutes are the products of investments of the skill. If a British statute deals with a problem which has arisen in a similar form in Ghana, it can save the hard-pressed Ghanaian legislative draftsmen a great deal of time to make use of the British investment, even if some re-wording is necessary. It is a form of technical assistance which is free for the taking. This is probably the main reason for the exceptional step taken in 1971, when the Courts Act incorporated into Ghanaian law sections of the English Law of Property Act, 1925. Presumably this 
was done because at that time the parliamentary draftsmen could not complete the task of drafting a Ghanaian statute for the purpose, a task which they completed (still making use of the British text) in the Conveyancing Decree, 1973. The same factor may have been a reason for the "slovenly" decision of the early legislature to adopt the statutes of general application. Ghana has now been able to clarify the law by specifying or enacting those British texts which are to be in force. But the economics of skilled manpower may still be the main reason why any of them are in force.

There is another advantage in the adoption of statutes from other jurisdictions even today. The best legislative draftsmanship cannot anticipate all problems of interpretation. If a text has already been in force elsewhere for some time, there is a probability that some of these problems will have been before the courts of that jurisdiction. These judicial discussions will be of assistance when the same problems arise in the new jurisdiction, and may even enable the problems to be avoided by textual amendments. Thus the effect of certain sections in the Ghana Moneylenders Ordinance has been settled by reference to decisions of the British courts on the British Moneylenders Act, 1927, and of the Privy Council on appeal from other commonwealth countries with similarly worded legislation ${ }^{16}$. However, this advantage should not be greatly stressed. The problems of interpretation which arise in Ghana are often problems which could not have arisen in Britain. For example, in applying the statutes of distribution the courts have encountered difficulty in interpreting the words "wife" and "child". These difficulties have arisen from the special nature of marriage and recognition of paternity under customary law, to which there is no equivalent in English law ${ }^{17}$.

Some of the foregoing arguments could have been used to justify the application of foreign statutes in general, rather than only British statutes. The reason why almost no non-British foreign statutes have been adopted lies in the history of the Ghanaian legal profession. This is the group which has a determinative voice in the drafting of legislation and is largely responsible for applying it when enacted. Its training has made it more able and inclined to apply British statutes than others. Further, given the considerable English element of Ghanaian law, British statutes have often been more appropriate for its development.

The arguments against the process should now be discussed. One has already been mentioned: that British statutes are not suitable for application to Ghanaian society. It has been seen that even in recent years the Ghanaian legislature has often rejected this. Furthermore, it applies with less force to class (5), which is now the most prominent, because here it is more likely that adjustments will be made for local conditions.

A further, general objection is that, for Ghana to be bound by the British legislature, is a negation of her sovereignty. This clearly applied to each addition to class (1). In this respect the argument has prevailed by the ending of colonial rule. It has also been said to apply after independence to class (3). The effect of applying the "law for the time being in force in England", as has been seen, was that the British Divorce Reform Act, 1969, automatically bound the Ghanaian courts. The present objection was urged particularly before and during the enactment of the

16 Yeboa v. Bofour [1971] 2 G. L. R. 199.

17 Ollennu, The Law of Testate and Intestate Succession in Ghana (1966), pp. 252-58. 
Ghana Matrimonial Causes Act, 1971, which changed this ${ }^{18}$. However, it is difficult to appreciate that Ghana's freedom was affected by the voluntary decision of the Ghanaian legislature to apply the British Acts in Ghana until such time as it decided, in its discretion, to enact otherwise. It may perhaps be argued that this was in effect a delegation of legislative power, and that such delegation should not be made in favour of a foreign legislature. However, in the absence of a rigid constitutional rule it is doubtful whether there is a substantial difference in terms of the status of the legislature between this instance and the delegation of wideranging powers to, for example, the government-appointed Prices and Incomes Board ${ }^{19}$. The sovereignty argument may be advanced as a reply to the view that English law is inherently superior to any other, but it has been suggested that that argument has no valid basis, and does not therefore need to be refuted by an opposed theory. The argument is closely allied to the arguments that British legislation is unsuitable to Ghanaian society, and that British legislation is inaccessible in Ghana (which will be advanced below). These, however, are strictly distinct arguments. Finally, it may be said that it creates an unfortunate impression in the public mind if post-independence British statutes are regarded as binding in the Ghanaian courts, especially today when the doctrine of "self-reliance" is officiallyaccepted policy. Apart from this aspect of public relations, the objection seems to have little strength.

Finally, an important practical argument against the enforcement of British statutes is that their texts are not readily available in Ghana. This did not apply with such force to class (1), because the government took care to ensure that the texts of important British enactments directed to Ghana should be available. They were published, for example, in the periodic editions of The Laws of the Gold Coast. It applied to all other classes except class (5), texts enacted in Ghanaian statutes. Class (2), statutes of general application, included at one time hundreds of statutes scattered among the chronological volumes of British statutes, ranging over centuries. Even class (7), which included sections from the Law of Property Act, 1925, only, gave rise to difficulties. These texts are not readily available even in Accra. In most other places a practitioner or judge would have to travel miles to read one. (It may be observed that the same problem arises from the continued applicability of English case-law; but that would be far more difficult of solution, and is not relevant here.) It has been noted that the Courts Act, 1971, proposed to deal with the problem by the publication in Ghana of a consolidated version of the relevant texts. This was not possible in earlier years, when there was uncertainty as to precisely which texts applied, and when their number was so great as to make the enterprise very expensive. It may now become unnecessary, because all applicable British texts are coming to be included in class (5). This is the one class which is not open to this objection. When a text has been enacted in a Ghanaian statute it is as accessible as any other Ghanaian enactment. Perhaps this is still insufficient, but the objection then is not one which arises from its foreign origin.

18 See e. g. the dictum in Dodoo von Dodoo (1970) C. C. 65; also Daniels, op. cit., pp. 142-143. However each lays greater emphasis on the objection that British statutes were made for a different type of

19 On policies concerning the delegation of legislative power, see Duff and Whiteside, "Delegata Potestas non Potest Delegare", Association of American Law Schools, Selected Essays on Constitutional Law (1938), Book 4, p. 291. The question was discussed in Gray [1971] 1 G. L. R. 422. 
In conclusion, recent developments may be summarised in terms of the policy considerations just discussed. British statutes have been part of Ghanaian law in seven ways. Class (1) was necessary to the colonial regime, but could not be allowed to continue after independence. It became obsolescent at that date, and has now disappeared. Classes (2), (3), (4), (6) and (7) were subject to the objections that they were not necessarily suitable for Ghanaian society, and consisted of texts which were comparatively inaccessible. The substantial arguments in their favour were that they were frequently suitable in fact, and that their importation did not require an entirely fresh exercise in drafting. Their disadvantages have led to their reduction to a short list of specified enactments and a few others, although the two-year life of class (7) from 1971 was a variation in the trend. Their advantages have been retained by the extension of class (5), which avoids the defects by providing the legislature with an occasion to make amendments, and produces comparatively widely distributed texts. It is likely that in a few years' time class (5) alone will remain, perhaps extending even more widely than today. In this way Ghana will continue to make use of the work of British parliamentary draftsmen while reducing to a minimum the disadvantages of receiving British statute law. 


\section{Africa and the Problems of International Law}

\section{By Marion Mushkat}

The doctrines of the Renaissance and the Enlightenment, reflecting the school of natural law, considered all men to have equal rights in human society.

With the coming of modern capitalism and its colonial and neoimperialistic trends, reflecting the school of positivism, the world was divided into civilized and noncivilized nations as a starting point for the constitutive approach to recognition and the justification of colonialism.

The recently established African states, following the claims of those in Asia, reject their classification by external forums as new members of the international community. They stress that they, too, came into existence through a reversion to sovereignty, expressing the right to selfdetermination.

This process of reversion is rooted not only in the position of the "new" states, but also in peoples still under foreign rule and fighting for de-colonization. The legitimacy of this fight is described as superseding even the commitments of the U. N. Charter to settle all disputes in a peaceful way and to refrain from the threat or use of force against the territorial or political independence of any state. The right of reversion to sovereignty is also presented as being connected to the right to assistance and economic privileges in order to end underdevelopment. Africa's impact on the Third World doctrines concerning such aid is eminent. The promotion of peaceful co-existence and the growing trends in international law reflect the need to pay more attention to problems of social justice.

This position should be considered as a transition from a negative to a positive approach to the role of international law. It remains clear, however, that the transformation of the law cannot be realized only through the pressures to the quantitively important states in Africa and in the Third World; it also depends on better cooperation with the developed countries, which are still qualitatively dominant in the international community.

\section{British Legislation as a Source of Ghanaian Law: From Colonialism to Technical Aid}

\section{By GoRdon WoOdMAN}

British statutes have constituted part of the law of Ghana from the establishment of the colonial legal system in 1874-76 to the present day. As a source of Ghanaian law they fall into seven categories.

(1) Legislation by the British parliament or crown after 1874, intended to apply in Ghana. This type ceased to grow when Ghana became independent in 1957, and has now disappeared.

(2) "Statutes of general application in force in England" in 1874. Since 1971 this has been restricted to a declining list of specific statutes.

(3) Statutes "for the time being in force in England" relating to probate and matrimonial causes and court procedure. These have been almost completely replaced by Ghanaian statutes.

(4) Statutes concerning admiralty jurisdiction. These ceased to apply in 1971.

(5) Statutes the texts of which have been incorporated in Ghanaian legislation. This class has increased since independence.

(6) The statutes of distribution, which govern certain cases of intestacy.

(7) Certain sections of the English Law of Property Act, 1925, in force in Ghana from 1971 to 1973.

Thus class (5) has increased, while all the others have declined, and in some cases disappeared.

Most of the arguments in favour of the application of British statutes in Ghana appear to be invalid or contrary to fundamental governmental policies today. However, there may be force in the view that Ghana can benefit from the 
investment of drafting skill contained in some British statutes. Of arguments against their application, the strongest seems to be that statutes designed for Britain are unlikely to be suitable for Ghanaian society. The present trend away from the application of British statutes per se, and towards the incorporation of their texts in Ghanaian enactments, suggests that the two arguments mentioned are decisive in decision-making today.

\section{Constitutional Storm in India}

BY S. C. SEN

India has recently had its greatest constitutional crisis since its independence in 1947. The Indian Constitution was framed in 1947 on a strong democratic base. The Constitution enshrined in a special chapter fundamental human rights which were considered to be inalienable. A strong Supreme Court rich in democratic traditions successfully functioned in India and was the guardian of constitutional rights.

The constitutional peace and tranquility and the democratic structure and the supremacy of the rule of law was recently the subject of a nationwide debate in India. Originating as a purely legal question it became both a political as well as legal issue. Supremacy of the Constitution, powers of the Parliament and independence of the judiciary all became subject-matter of the great debate. After a historic decision of the Supreme Court three judges of the Supreme Court of India were superseded and resigned in protest and lawyers were in revolt all over the country. An element of high dramatic tragedy was introduced when a Cabinet Minister who most vocally supported the supersession of judges died in an air crash. The article describes in detail the whole episode and its implications.

\section{Elections for President in Turkey March-April 1973}

\section{By G. Papadimitriu}

The article deals with the provisions about the election of the Turkish President. On this background, the facts of the Turkish presidential election in Spring 1973 are presented. The author then reviews the constitutionality of this election. He concludes that the military has - in violation of the language and the spirit of the constitution - attempted to manipulate the election by reducing the choice of the competent organ (The Great Turkish National Assembly) to one person sympathetic with the views of the military. However, the author does not go along with assumption that the election was in toto unconstitutional; such a verdict would be, in his opinion, simplifying and formalistic. This judgement is supported by some remarks about the ongoing factual constitutional process of revision as highlighted by the described election. These remarks clearly point to the weakening of the liberal and democratic character of the 1961 constitution; conservative features with reactionary elements are obvious. 